\title{
NAZWY GEOGRAFICZNE Z OBSZARU SIEDEMNASTOWIECZNEJ POLSKI I TERENÓW OŚCIENNYCH W PAMIĘTNIKU FRANCISZKA DALERACA „LES ANECDOTES DE POLOGNE OU MEMOIRES SECRETS DU REGNE DE JEAN SOBIESKI III DU NOM"
}

Słow a tematyczne: onimia, nazwa geograficzna, adaptacja językowa, tłumaczenie, pamiętnik

Spośród licznych dzieł o charakterze pamiętnikarskim poświęconych Polsce w okresie przedrozbiorowym, których autorami byli cudzoziemcy (Targosz, 1997, s. 39) odwiedzający przy różnych okazjach Rzeczpospolitą szlachecką czy przebywający w niej dłużej, na uwagę badaczy zainteresowanych kontaktami językowymi zasługuje przede wszystkim obszerne, dwutomowe dzieło Francuza Franciszka Daleraca pt. „Les anecdotes de Pologne ou memoires secrets du regne de Jean Sobieski III du nom" ". Pamiętniki ukazały się drukiem w Amsterdamie w 1699 r., a o tym, że cieszyły się znaczną poczytnością niech świadczy fakt, że już w tym samym roku wydano je w Paryżu², zaś w 1700 r. dokonano ich przekładu na język niderlandzki i angielski. Autor był dworzaninem króla Jana Sobieskiego, powiernikiem królowej Marysieńki, uczestnikiem bitew pod Wiedniem i Parkanami, który w trakcie misji dyplomatycznych i wypraw do Francji dostał się do niewoli tureckiej, a wykupił go sam król. Przeżył też wiele innych równie niebezpiecznych, co ciekawych przygód. Pamiętniki nie były spisywane na bieżąco, a opisane w nich wydarzenia rozgrywają się w ciągu kilkunastu lat u schyłku XVII wieku (Folkierski, 1925, s. 5-7; Targosz, 1991, s. 105108; 1992, s. 112-113). Tekst oprócz opisu konkretnych wydarzeń historycznych

${ }^{1}$ François Paulin Dalairac (inne warianty nazwiska: Dallerac, d'Allayrac) (Folkierski, 1925, s. 5). Współczesna postać tytułu: „Les anecdotes de Pologne ou mémoires secrets du règne de Jean Sobieski III du nom".

${ }^{2}$ Wydanie paryskie jest również dostępne w bibliotece cyfrowej Polona (zob. wykaz literatury). 
(kampania wiedeńska, wyprawy mołdawskie Jana Sobieskiego) zawiera ,[...] wcale bystre spostrzeżenia obyczajowe, tyczące się wojska (widzi w niem autor, przy równoczesnym, krańcowym podziwie dla Sobieskiego, przerażające oznaki słabości i rozkładu), zbytków szlacheckich (wspaniałe stypy) czy też i stosunku do poszczególnych prowincyj, z których Ukrainę określa jako «polskie Peru»" (Folkierski, 1925, s. 6). Obserwacje Daleraca dotyczyły nie tylko ówczesnej Polski i jej obywateli, ale także ziem i zwyczajów innych narodów czy grup etnicznych (m.in. Turków, Tatarów, mieszkańców Mołdawii i Wołoszczyzny). Mapę wydarzeń opisanych w „Les anecdotes...” wyznaczają wyjazdy autora z Polski do Francji, Rzymu, pod Wiedeń, a także podróże z dworem królewskim, Janem Sobieskim i Marią Kazimierą po Polsce i krajach ościennych. Dzieło wydaje się tym bardziej godne zainteresowania językoznawcy, że do tekstu francuskiego wpleciono bogaty różnojęzyczny materiał onimiczny (zarówno nazwy osobowe, jak i geograficzne, które w druku zapisano kursywą), a także leksykę odnoszącą się do realiów związanych z przemierzanymi przez autora ziemiami, uwagi z zakresu etymologii różnych nazw oraz liczne komentarze natury językowej, które pozwalają sądzić, że autor charakteryzował się niemałym zacięciem lingwistycznym. Spory zbiór — jeśli nie większość tych wtrętów — stanowi materiał polskojęzyczny. W perspektywie wielojęzyczności autora, posługującego się także polszczyzną, przeplatanie tekstu francuskiego cytatami innojęzycznymi należy uznać za przejaw różnego typu wykładników transkodowych znamiennych dla tekstów bilingwalnych (code-switching, code-mixing, interferencje) (Hamers, Blanc, 1983, s. 78, 199, 204, 455).

Warto tu także wspomnieć, że Dalerac pozostawił po sobie również inny pamiętnik pt. „Memoires du Chevalier de Beaujeu”, w którym zrelacjonował wydarzenia wcześniejsze niż te opisane w „Les anecdotes...”, wydany po raz pierwszy w Paryżu w 1698 r. (drugie i trzecie wydanie - Amsterdam 1700 r. i 1722 r.; zob. Dalerac, 1883, s. XIV; Targosz, 1992). W niniejszym opracowaniu ze względu na ograniczenia objętościowe pomijam zawarte w „Memoires...” nazwy, wobec których autor stosował podobne jak w „Les anecdotes...” zabiegi dotyczące formy językowej onimów oraz sposobów ich wprowadzania do tekstu i prezentacji. Ponadto ważnym kontekstem dla „Les anecdotes...” są dwa częściowo polskie przekłady: pochodzące z 1689 roku rękopiśmienne anonimowe thumaczenie pt. „Historya woyny wiedeńskiey z Turkami Jana III króla polskiego", które obejmuje wstęp i pierwsze trzy rozdziały pierwszego tomu ${ }^{3}$, oraz

${ }^{3}$ Za zwrócenie mi uwagi na istnienie tego rękopisu w zasobach Zakładu Narodowego im. Ossolińskich (sygn. 1993/I) serdecznie dziękuję Panu Dariuszowi T. Wielcowi. Moje dotychczasowe poszukiwania dalszego ciągu pamiętnika ani próby ustalenia autorstwa nie przyniosły rezultatu. Nie wydaje się, żeby autorem wersji polskiej był sam Dalerac, który znał polski i thumaczył z polskiego na francuski, ale $\mathrm{z}$ tłumaczeniem $\mathrm{z}$ francuskiego na polski mógłby mieć problemy (wiązałoby się 
dziewiętnastowieczne, również rękopiśmienne tłumaczenie Józefa Szlezygiera pt. „Pamiętniki Daleraka z czasów panowania Jana III”4 (Szlezygier, b.r.).

Celem opracowania jest przyjrzenie się utrwalonym w „Les anecdotes...” nazwom geograficznym, odnoszącym się do obiektów położonych w obrębie państwa polskiego w drugiej połowie XVII wieku, zwłaszcza zaś na obszarze dawnych Kresów południowo-wschodnich (Podola z Kamieńcem i Ukrainy prawobrzeżnej), a także — w mniejszym zakresie — nazwom wskazującym na miejsca leżące poza granicami (przede wszystkim wschodnią i południowo-wschodnią) ówczesnej Polski, ale mocno związane z polską historią, będące areną ważnych dla Polski wypadków dziejowych (Mołdawia, Wołoszczyzna, Bukowina). Pomijam obszerny zbiór choronimów europejskich (francuskich, włoskich, niemieckich, tureckich, węgierskich, czeskich, słowackich, południowosłowiańskich itd.) zawartych w pamiętniku, ale mniej istotnych dla historii I Rzeczpospolitej. Interesować mnie będzie przede wszystkim forma językowa przytaczanych nazw geograficznych, różne zabiegi adaptacyjne, a także uwagi o charakterze metajęzykowym odnoszące się do warstwy onimicznej. Obserwacja tych zagadnień zdaje się wiele mówić na temat onimicznej świadomości autora, w szerszym zaś ujęciu — jego świadomości językowej i wielojęzyczności. Dalerac prócz znajomości rodzimej francuszczyzny, łaciny i języka włoskiego, zdobył całkiem niezłe rozeznanie w zakresie polszczyzny, co było konsekwencją jego dość licznych i długotrwałych (trzynastoletnich) kontaktów z nosicielami języka polskiego na dworze króla Jana Sobieskiego. Tłumaczył zresztą z polskiego na język francuski relację o zwycięstwie wiedeńskim (Targosz, 1992, s. 118). Zarówno względy językowe związane z zainteresowaniami lingwistycznymi, przejawiającymi się notowaniem dubletów, komentarzami etymologicznymi, morfologicznymi i semantycznymi, jak i redakcyjne (uwagi i glosy marginalne) przesądzają o wyjątkowości pamiętnikarskich relacji Daleraca. Na marginesie warto dodać, że nazwy użyte przez autora są lub były realne i identyfikacja wskazanych przez nie obiektów zwykle nie nastręcza trudności (zob. MP; MU; MWB; SG). W kontekście zawartych tu rozważań szczególnie istotny wydaje się

to bowiem z doskonałym opanowaniem polszczyzny także w piśmie). Dalsze badania nad polskim przekładem mogą rzucić pewne światło na problem jego autorstwa. Zastanawia również data wskazana na karcie tytułowej rękopisu — 1689 rok, co świadczyłoby o tym, że powstał on przed opublikowaniem francuskiego oryginału. Tłumacz mógł dysponować francuskim manuskryptem, przy czym obecnie fakt ten pozostaje w sferze hipotez.

${ }^{4}$ W wydanym w 1883 r. w Krakowie (w serii „Pamiętniki do czasów Jana III. Wydał Wł. Markowski”, dedykowanej Franciszkowi Kluczyckiemu) polskim przekładzie pt. „Pamiętniki kawalera de Beaujeu" (za kawalerem de Beaujeu krył się F. Dalerac; zob. Targosz, 1992; 1997, s. 37) Alexandra Kraushara (1883) zapowiedziano pełny przekład tekstu Daleraca, który miał się ukazać w tomie II i III serii pt. „Pamiętniki Franciszka Daleraca...” autorstwa Józefa Szlezygiera (opracowanie przypisów powierzono Julianowi Bartoszewiczowi). Przekład ten nie został opublikowany, a istnieje jedynie w wersji rękopiśmiennej (zob. Szlezygier, b.r.). 
sąd Halszki Górny (2013, s. 115) dotyczący specyfiki i funkcji zasobów proprialnych w piśmiennictwie pamiętnikarskim: „Nomina propria $\mathrm{w}[\ldots]$ tekstach [pamiętnikarskich — R.Z.] współtworzą kategorię przestrzeni i czasu w jej wymiarze realnym (np. geograficznym), ale także symbolicznym, mentalnym, tekstowym, a określenie czasu i miejsca zdarzeń wpisuje się niejako z definicji m.in. w schematy autonarracyjne".

Na problem włączania do utworu nazw geograficznych (choć trzeba dodać, że w pamiętniku pojawia się również obszerny zbiór antroponimów) o różnych korzeniach i rozmaitej etymologii należy patrzeć z kilku perspektyw językowych: rodzimego języka autora, a zatem francuszczyzny, języka polskiego oraz innych języków (niemieckiego, włoskiego, tureckiego, węgierskiego, innosłowiańskich itd.). Wiąże się to z faktem, że zgodnie z postulatami Daleraca zawartymi we wstępnych partiach pamiętnika przywoływany materiał onimiczny pojawiał się $\mathrm{w}$ formie zbliżonej do wymowy danego języka, z którego obszaru pochodził bądź dotyczył:

[...] d'écrire les noms propres des personnes, des lieux, et des choses selon qu'on les prononce en chaque langue; mettant l'orthographe dans les marges autant qu'on l'a pû, c'est qui n'est pas beaucoup dire, puisque l'auteur ne sçait point l'Allemand, le Turc ni le Hongrois assez bien pour pouvoir décider là-dessus. Quant au Polonois, il a pris les avis des gens de la Nation, qui l'ont aidé à mettre les noms propres un peu plus correctement que ceux des autres langues, dont il n'a pas tant de connoissance 5 .

Zasadniczo jednak nazwy genetycznie obce były wplatane w tekst podstawowy w postaci mniej lub bardziej zaadaptowanej (graficznie, fonetycznie, morfologicznie, składniowo) do francuszczyzny, natomiast formy naśladujące oryginalną (czyli charakterystyczną dla języka, z którego nazwa pochodziła lub w którym funkcjonowała) wymowę i/lub oryginalny zapis autor umieszczał w glosach marginesowych. Powzięta ambitna praktyka musiała w konsekwencji prowadzić do różnych błędów, zwłaszcza że zamieszczony materiał onimiczny w zdecydowanej większości pochodził z języków typologicznie odległych od francuszczyzny, zresztą nie tylko indoeuropejskich (np. z węgierskiego i tureckiego). W rezultacie z jednej strony czytelnik ma możliwość obserwacji w tekście nazw w kształcie tożsamym lub zbliżonym do form oryginalnych, na czym de facto zależało

${ }^{5}$ Strona nienumerowana, wstęp do tomu I. Przykłady pochodzące z glos marginesowych poprzedzam asteryskiem $(*)$. Cytaty francuskie podaję w oryginalnej pisowni siedemnastowiecznej, przy czym każdorazowo zamieniam długie $s(f)$ na $s$ oraz modernizuję pisownię wielkich i małych liter. W wypadku dłuższych fragmentów zamieszczam własne tłumaczenia: „Pisownia nazw własnych osób, miejsc, rzeczy według wymowy w każdym języku, z uwzględnieniem w miarę możliwości ortografii na marginesach, która może być niedokładna, gdyż autor nie znał na tyle dobrze niemieckiego, tureckiego ani węgierskiego, by mieć całkowitą pewność. Co do polszczyzny autor uwzględniał uwagi Polaków, którzy pomagali mu zapisywać nazwy własne nieco poprawniej niż pochodzące z innych języków, których nie miał wystarczającej znajomości”. 
Daleracowi najbardziej, z drugiej zaś dostrzegamy zmagania pamiętnikarza z przystosowaniem do frankofońskiego ucha wielu, często bardzo egzotycznych onimów.

Warto wspomnieć, że na podstawie zarówno apelatywnej, jak i proprialnej leksyki użytej przez Daleraca możemy także wyciągać wnioski dotyczące języka drugiej połowy XVII wieku. Zgromadzony materiał odzwierciedla stan polszczyzny końca doby średniopolskiej z charakterystycznymi dla niej zjawiskami (także regionalnymi), o czym już pisano (Zarębski, 2018, s. 19-23).

Jeśliby rozpatrywać badane propria $\mathrm{w}$ kontekście funkcjonujących $\mathrm{w}$ onomastyce, aczkolwiek nie bez pewnych zastrzeżeń (Wolnicz-Pawłowska, 2006, s. 84-87) ${ }^{6}$, terminów egzonim i endonim, to tylko część nazw geograficznych pojawiających się we francuskim tekście mieści się w obrębie egzonimów, np. Pologne, Varsovie. Znaczna grupa onimów występuje w formie oryginalnej lub do niej zbliżonej, np. Brody, co wiązało się z zamierzoną i świadomie stosowaną praktyką ich transpozycji. Nazwy z obszaru I Rzeczpospolitej (oraz innych krajów i krain, które autor przemierzał w trakcie wędrówki) w dużej mierze stanowiły dla niego, najogólniej rzecz biorąc, jednostki obce, których zapis niejednokrotnie nastręczał trudności.

Zbiór nazw geograficznych z obszaru Polski siedemnastowiecznej, wschodnich i południowo-wschodnich rubieży oraz terenów przygranicznych w tekście Daleraca jest obszerny, obejmuje bowiem ponad sto, nie licząc wariantów pisownianych i wymawianiowych. Wiele z nich charakteryzuje się znaczną frekwencją, np. Dniestre, Grodno, Caminieck, Kiovie, Yassi, Yavorouf, Zolkief. Ponadto trzeba pamiętać o obecności w pamiętniku pokaźnej grupy toponimów odnoszących się do obiektów znajdujących się poza Polską, np.: Allemagne 'Niemcy', Boheme 'Czechy', Caffa 'Kaffa; Teodozja', France 'Francja', Hongrie 'Węgry', Moravie 'Morawy', Moscovie/Moskou 'Moskwa', Nitra 'Nitra', Süede 'Szwecja', Vienne 'Wiedeń'.

Nazwy geograficzne ${ }^{7}$ wskazujące miejsca $z$ interesującego nas obszaru reprezentują kilka kategorii onimicznych, związanych z rozmaitymi klasami obiektów:

- nazwy państw (w sensie współczesnym), np. Lithüanie (pol. Litwa, lit. Lietuva), Pologne (pol. Polska), Russie (pol. Rosja, ros. Poccuя), Ukraine (pol. Ukraina, ukr. Україна);

${ }^{6}$ Ewa Wolnicz-Pawłowska (2006, s. 86, 90), choć uważa, iż „[...] z językoznawczego punktu widzenia — podział na egzonimy i endonimy nie ma większego sensu”, nie neguje posługiwania się tymi terminami, postulując jednocześnie popularyzację terminów alonim (każda z nazw odnosząca się do tego samego obiektu) i egzonim historyczny (egzonim używany niegdyś).

${ }^{7} \mathrm{~W}$ odniesieniu do nazw z szeroko pojętego pogranicza polsko-wschodniosłowiańskiego w związku ze skomplikowanymi dziejami tych terenów zamieszczam także współczesne odpowiedniki innojęzyczne. Podaję tu zapisy z tekstu głównego, zaś warianty nazw odnotowuję w dalszych partiach artykułu. W przypadku kategorii: nazwy miast oraz mniejszych osad, ze względu na uwarunkowania historyczne, klasyfikacji dokonano dość arbitralnie. 
- nazwy krain historycznych i geograficznych, np.: Besarabie (pol. Besarabia, rum. Basarabia, ukr. Бесарабія), les Bouccovines (pol. Bukowina, rum. Bucovina, ukr. Буковина), le Boudgiac (pol. Budziak — kraina historyczna będąca częścią Besarabii, ukr. Буджак, rum. Bugeac), la Courlande (pol. Kurlandia, tot. Kurzeme, niem. Kurland), la Krimée (pol. Krym, ukr. Kpuм, ros. Kpblм), la Livonie (pol. Liwonia, łot. Vidzeme, niem. Livland, łac. Terra Mariana), la Moldavie (pol. Mołdawia, rum. Moldova, ros. Молдавия), la Moravie (pol. Morawy), la Podlakie (pol. Podlasie, biał. Падляшша, ukr. Підляшшя, lit. Palenke, łac. Podlachia), la Podolie (pol. Podole, łac. Podolia, ukr. Поділля, ros. Подолье, rum. Podolia), Pokucie (pol. Pokucie, ukr. Покутmя, rum. Pocuția), Pomeranie (pol. Pomorze), la Samogicie (pol. Żmudź, łac. Samogitia, lit. Žemaitija), Severie (pol. Siewierszczyzna, ros. Северщина, ukr. Сіверщина), Silesie (pol. Ślask), la Valakie (pol. Wołoszczyzna, rum. Valahia), la Volhynie (pol. Wotyń, ukr. Волинь), la Transylvanie (pol. Transylwania), Warmie (pol. Warmia);

- nazwy miast, np.: Bakouf (pol. Baków, rum. Bacău), Bar (pol. Bar, ukr. Бар), Belts (pol. Betz, ukr. Белз), Bengin (pol. Będzin), Bialogrod (pol. Białogród nad Dniestrem, ukr. Білгород-Дністровський), Boknia (pol. Bochnia), Bouchach (pol. Buczacz, ukr. Бучач), Boutsko (pol. Busk, ukr. Буськ), Bratslawie (pol. Bractaw, ukr. Браилав), Breslaw (pol. Wrocław), Bretch (pol. Brześć, biał. Брэст, ros. Брест, Берестье, ukr. Берестя), Brody (pol. Brody, ukr. Бродu), Chenstokova (pol. Częstochowa), Chernikovie (pol. Czernihów, ukr. Черніzів, ros. Чернигов), Cotchim (pol. Chocim, ukr. Хотин, rum. Hotin), Cracovie (pol. Kraków), Crotchin (pol. Kruczyn), Dantsiek (pol. Gdańsk), Dwortsé (pol. Dworce, ukr. Двipui), Giviets (pol. Żywiec), Glivietz (pol. Gliwice), Gnesne (pol. Gniezno), Grodno (pol. Grodno, biał. Гродна, Горадня, Гародня, ros. Гродно, lit. Gardinas), Halich (pol. Halicz, ukr. Галич), Kaminieck (pol. Kamieniec Podolski, ukr. Кам'янець-Подільський), Kelms (pol. Chetm, ukr. Холм), Kilia (pol. Kilia Nowa; Kilia Stara, ukr. Кілія), Kiovie (pol. Kijów, ukr. Kuïв), Leopol (pol. Lwów, ukr. Львiв), Lovith (pol. Łowicz), Lublin (pol. Lublin), Lubownia (pol. Lubowla, słow. Stará Lubovňa), Minski (pol. Mińsk, biał. Мінск, ros. Минск), Nadarzyn (pol. Nadarzyn), Novogrodek (pol. Nowogródek, biał. Навагрудак, ros. Новогрудок), Pietrecouf (pol. Piotrków Trybunalski), Podahiets (pol. Podhajce, ukr. Пidzaŭui), Polotsko (pol. Połock, biał. Полаик, ros. Полоик), Posnanie (pol. Poznań), Primislie (pol. Przemyśl, ukr. Перемишль), Przévorska (pol. Przeworsk, ukr. Переворськ), Ratibor (pol. Racibórz), Reetchouf (pol. Rzeszów), Sambor (pol. Sambor, ukr. Самбip), Samotitzé (pol. Samocice), Sbarach (pol. Zbaraż, ukr. 3бараж), Schniatyn (pol. Śniatyn, ukr. Снятин), Siradie (pol. Sieradz), Skolia (pol. Skole, ukr. Сколе), Slotehouf (pol. Zloczów, ukr. Золочiв), Smolensko (pol. Smoleńsk, ros. Смоленск, biał. Смаленск), Sotchova (pol. Suczawa, rum. Suceava, ukr. Cучава), Stanislaf 
(pol. Stanisławów, Iwano-Frankiwsk, ukr. Івано-Франківськ), Strye (pol. Stryj, ukr. Стрий), Sborouf (pol. Zborów, ukr. 3боpiв), Tarnosky Goury (pol. Tarnowskie Góry), Tarnouf (pol. Tarnów), Tcherrim (pol. Czehryń, ukr. Чигирин), Tismenitz (pol. Tyśmienica, ukr. Тисмениця), Tlomasch (pol. Tłumacz, ukr. Тлумач, hist. Tовмач), Trok (pol. Troki, lit. Trakai), Warsovie/Varsovie (pol. Warszawa), Wilna (pol. Wilno, lit. Vilnius), Yaroslave (pol. Jarosław, ukr. Яро́слав), Yasloviets (pol. Jazłowiec, ukr. Язловець), Yassi (pol. Jassy, rum. Iași), Yavorouf (pol. Jaworów, ukr. Яворів), Zamosch (pol. Zamość, ukr. Замостя), Zolkiew (pol. Żótkiew, ukr. Жовква);

- nazwy mniejszych osad (miasteczek, wsi, osiedli, twierdz i fortec, rezydencji królewskich), np.: Bouk (pol. Nowy Boh, ukr. Новий Буг), Cetsora (pol. Cecora, rum. Țuțora), Chemerits (pol. Czemerica), Chernielitsé (pol. Czernielica), Chimernie (pol. Czemierniki), Falcin (pol. Falczyn, rum. Fălciul), Goura (pol. Góra), Yanouf (pol. Janów, ukr. Іванів), Jovanietz (pol. Żwaniec, ukr. Жванець), Jurafno (pol. Żurawno, ukr. Журавно), Kalnic (pol. Kalnyk, ukr. Кальник), Krivé (pol. Krzywe, ukr. Криве), Lороисhnа (pol. Łopиszna, ukr. Лопушня), Lobzouf (pol. Łobzów), Megdibouge (pol. Międzybóż, ukr. Меджибiж), Olessko (pol. Olesko, ukr. Олесько), Outch (Viez) (pol. Uście Zielone, ukr. Устя-Зелене), Регесор (pol. Perekop, ukr. Перекоn), Perérita (pol. Pererita), Peréüolok (pol. Przewłoka, ukr. Переволока), Pietrovitzé (pol. Piotrowice), Potok (pol. Potok Złoty, ukr. Золотий Потік), Prague (pol. Praga; dzisiejsza dzielnica Warszawy), Tarnovits (pol. Tarnowice), Vessolo (pol. Wesoła), Vilanouf (pol. Wilanów), Vissotsko (pol. Wysocko, ukr. Висоиько), Vitouf (pol. Witów);

- nazwy gór, np.: Monts de Crapac (Montes Carpatici) (pol. Karpaty, ukr. Kapnámu, słowac. Karpaty, rum. Carpaţi), Niédobor (Miodobory, Tottry, ukr. Товтри, Толтри);

- nazwy wodne: nazwy mórz, np.: Mer Noire (pol. Morze Czarne, ukr. Чóрне мо́pe), rzek, np.: le Bouk (pol. Boh, ukr. Південний Буг), Dnieper (pol. Dniepr, ukr. Дніпро), Dgitja (pol. Jijia, Żyżija, rum. Jijia, ukr. Жижія), Dniestre (pol. Dniestr, ukr. Днiстер), Oder (pol. Odra), Prout (pol. Prut, ukr. Прym, rum. Prut), Sân (pol. San, ukr. Сян), Sereth (pol. Seret, ukr. Cepem), Smotrix (pol. Smotrycz, ukr. Смотрич), Strepa, Vistule (pol. Wista) i jezior, np.: Lac d'Ovide (pol. Jezioro Owidiusza).

Przywołany repertuar onimów stanowi ciekawy obiekt badań z zakresu tej subdysycypliny, którą Artur Gałkowski określa mianem onomastyki translatorycznej (Gałkowski, 2018). Spektrum technik adaptacyjnych stosowanych wobec nazw obcych jest rozległe. Rozmaite bywają klasyfikacje tych mechanizmów (zob. Cieślikowa, 1996; Ballard, 2001, s. 27-30; Gałkowski, 2018; Sanz Espinar, 2008; Wolnicz-Pawłowska, 2014), choć — najogólniej rzecz ujmując — onimy 
przedostają się do języka docelowego wskutek: translokacji (przeniesienia nazwy w formie oryginalnej), adaptacji językowej (graficzno-fonetycznej, morfologicznej, składniowej) lub tłumaczenia przy użyciu ekwiwalentów semantycznych.

Zupełnie sporadycznym zjawiskiem w dziele Daleraca jest zastępowanie nazw oryginalnych francuskimi ekwiwalentami semantycznymi. Zabieg ten zastosowano wyłącznie w odniesieniu do form rozpowszechnionych w formie przetłumaczonej w języku francuskim, np. la Mer Noire (Morze Czarne). Częściej natomiast autor notuje różnojęzyczne warianty leksykalne pewnych nazw, np. Boristene/Boristhene/*Dnieper en langue du pays/*Dniepre, Falcin/Les Cartes écrivent Falxin, Ouy-War (tur.)/Nehausel (niem.)/Nowé Zamki (pol.)/Château Neuf (fr.)/Oüvarinum (łac.), Oppava en Latin/ Tropau en Allemand/Oppava en Polonois, des monts des Crapac/mons de Krapak/monts (montagnes) de Krapac/Montes Carpatici, Warmiel Warmeland (niem.), Braünsberg/nous disons Bronsberg, Heïesberg/ily en a qui disent Hiersberg, Fraonbourg/*en Latin Franco burgum/en Italien Francoburgo/[...]. En François nous disons Francbourg, Tloumatch/ appellé Plomach, Kilia Nova \& Kilia Stara/Kilia la Neuve, Kilia la Vieille, Bakouf ou Bakova/Et Latin Bacovie/Bacovia, Dniestre/Les Turcs l'appellent Tourla/du mot Latin Tyrus .

Warto wspomnieć, że gdy znane są Daleracowi przypadki oznaczania przez tę samą nazwę różnych miejsc, stara się on dostrzegać to zróżnicowanie, jak ma to miejsce w odniesieniu do toponimu Kaminiec: „Kaminiec, capitale de Podolie *Kaminiec Podolski, c'est à-dire Podolien, ou de Podolie; pour le distinguer d'une autre Kaminiec, qui est en Masovie, \& une starostie considerable"8.

Jeśli zaś chodzi o metodę polegającą na przeniesieniu onimu bez żadnych zmian w stosunku do oryginału, które Michel Ballard (2001, s. 18) określa jako „zerowy stopień przekładu elementu znaczącego” („le degré zéro de la traduction du signifiant"), np. Bar, Brody ${ }^{9}$, Grodno, Lublin, Lubownia, Nadarzyn, Olesko, Pokucie, Potok, Sambor, to bywa ona rozmaicie realizowana przez autora. Trzeba przy tym podkreślić, że nawet mimo pełnej translokacji nazwy te zostały naznaczone adaptacją fleksyjno-składniową, co wyraża się w blokadzie charakterystycznej dla polszczyzny fleksji w odpowiednich kontekstach składniowych, np. à Grodno, de Sambor. Ponadto forma niektórych translokowanych onimów mogła być do tego stopnia transparentna dla reguł języka francuskiego, że przeniesienie ich w całości nie powodowało większych trudności artykulacyjnych, np. Potok,

\footnotetext{
${ }^{8}$ Autor też objaśnia etymologię tej nazwy, tak jak to czyni w odniesieniu do niektórych innych onimów (zob. II/261). „Kaminiec, stolica Podola - Kaminiec Podolski, czyli Podola, by go odróżnić od innego Kamińca, który jest na Mazowszu; ważne starostwo".

${ }^{9} \mathrm{~W}$ tekście pojawiają się też odpowiedniki z oznakami adaptacji: Brodi, Brodij.
} 
Sambor. Zdarza się, iż postać oryginalna onimu (w pełni translokowana) występuje wyłącznie w glosie marginesowej, bez żadnych komentarzy dotyczących wymowy czy pisowni, np. *Iurawno; ewentualnie z objaśnieniem geograficznym, np. „*Praga, village au-delà de la Vistule vis-à-vis de Warsowie"10 (w tekście zasadniczym Prague).

W obrębie szeroko rozumianej techniki translokacji nazw należy umieścić te formy, które autor wysunąwszy do glos marginesowych, poprzedził uwagami typu s'écrit; les Polonois écrivent 'pisze się; Polacy piszą', np. *Bakow, *Bog, *Braçlaw, *Buçko (s'écrit Buçko avec la cedille qui fait prononcer le mot comme s'il y avoit un s, en cette sorte Boutsko) ${ }^{11}$, *Budziaki, *Dziza, *Yaslowiéç, *Halicz, *Lopuczna, *Międzybôz, *Plohuw, *Podaïeç, *Podohortsé (Podorets à l'accusatif), *Prut, *Przéworska, *Sbaracz, *Sborow, *Stoczow, *Sniatyn, *Sotczowa, *Stanislawow, *Czerryn/Czerrin 'Czehryń', *Uscié, *Viez, *Zolkieuv, *Zurawno, *Zwanieç. Zapisy te w zamierzeniu autora miały wiernie naśladować polską pisownię i mimo że — jak podkreśla Dalerac — były weryfikowane przez Polaków, to jednak część z nich pojawiła się w postaci zniekształconej.

Za odrębny przejaw przeniesienia nazw oryginalnych należy uznać zamieszczone w komentarzach marginesowych (zazwyczaj obok uwag na temat pisowni) próby uproszczonego zapisu fonetycznego niektórych onimów, co miało skutkować pokazaniem sposobu ich wymowy w języku polskim. Warianty te są poprzedzone francuskimi formułami typu: se prononce; les Polonois disent; il faut pronnoncer 'wymawia się; Polacy mówią; należy wymawiać', np.: *Bratslaf, *Dgitja, *Iolkief, *Podhayietz, Podahietz (on dit ordinairement Podahis) ${ }^{12}$, *Sotczowa, *Ioaniets \& Jovaniets (Le z \& le w sifflant un peu comme l'i \& l'o) ${ }^{13}$, *Jurafno, Tloumatch, Tcherrim, Krimee (On dit en ce pays là Krim) ${ }^{14}$, Samotitzé (tous les $z$ de ces noms doivent estre prononcez comme des $s)^{15}$. Zabieg ten miał na celu ułatwienie czytelnikowi francuskiemu wymowy egzotycznych nazw, przy czym i w tym zakresie nie zawsze udało się autorowi uniknąć usterek czy wahań, np. Podhayietz/Podahietz/Podahis. Niekiedy odnotowuje fakt błędnej wymowy francuskiej, np. nous disons par corruption Cestokova ${ }^{16}$.

Pamiętnik Daleraca — jak wiadomo - przeznaczony był dla odbiorcy francuskojęzycznego, wobec czego nie może dziwić to, że w tekście zasadniczym z reguły pojawiają się nazwy w postaci sfrancuszczonej, będącej wynikiem asymilacji

\footnotetext{
10 „Praga, miasteczko za Wisłą, naprzeciwko Warszawy”.

11 „Pisze się Buçko z cedyllą, co sprawia, że słowo wymawia się tak, jakby było s; stąd Boutsko”.

12 „Zwykle mówimy Podahis”.

13 "Z i w syczą trochę jak i oraz o".

„W tym kraju mówi się Krym”.

„Każde $z$ w tych nazwach musi być wymawiane jak $s$ ”.

„Mówimy błędnie Cestokova”.
} 
graficzno-fonetycznej ${ }^{17}$ (Ballard, 2001, s. 28-31), np.: Belts, Bengin, Bialogrod, Boknia, Bonef, Bouchach, Bouk, Boutsko, Bretch, Chemerits, Chernielitsé, Chernickovie, Chimernie, Dgitja, le Dniestre, Falcin, Giviets, Glivietz, Gnesne, Goura, Yassi, Yavorouf, Jurafno, Kelms, Kiovie, Krivé, Krotchin, Leopol, Lobzouf, Lopouchna, Lovith, Süblin ${ }^{18}$, Meggibouge, Minski, Moskou, Niédobor, Novogrodek, Oulch, Ouch, Outch 'Wieś', Perecop, Peréüolok, Pietrecouf, Pietrovitzé, Pilikvitzé, Plouhouf, Podolie, Polotsko, Posnanie, Prague, Primislie, Prout, Przévorska, Ratibor, Samogice, Sân, Sbarach, Sereth, Severie, Siradie, Smolensko, Semotrix, Stanislaf, Stenay, Strepa, Strye, Sborouf, Tarnovits, Tarnouf, Tismenitz, Tlomasch/ Plomach, Tloumatch, Trok ${ }^{19}$, Vessolo 'Wesoła', Vissotsko, Vitouf, Warmie, Wilna, Zamosch.

Adaptacja może mieć różne oblicza — od obejmującej tylko niektóre właściwości nazwy (zwłaszcza graficzno-fonetyczne), np. Diestre, Novogrodek, Wilna, po głębszą, np.: Czenstokova, Outch. Wskutek wdrożenia mechanizmów przystosowawczych pewne onimy, zwłaszcza zawierające trudne dla Francuzów spółgłoski i grupy spółgłoskowe, wydają się mocno zniekształcone, np. Tcherrim. Część asymilowanych propriów pojawia się w formach obocznych, co stanowi refleks trudności, jakie autor napotykał w procesie przyswajania ich do języka francuskiego, np.: BakouflBakova, Boudgiac/Boudgiak, BractslaflBratslavie, Brodi/Brodij, Cetsora/Cetzora, Chenstokova/Cestokova/Czenstokova, Yaroslave/Yaroslawe, Yaslovietz/Yasloviets, Jouanietz/Jovanietz/Joüanietz/Joüaniets, Halich/Alich, Caminieck/Caminiek/Kaminieck/Kaminiec/Kaminiek, Kotchim/Kotchym/Cotchim, Krimee/Krimée, Oulch/Outch (Viez), Perérita/Pererita, Podahiets/Podahietz, Podohors/Podohortsé, Reetchouf/Rechouf, Schmiatyn/Schniatyn/Schigniatyn/ Schigniatin, Slotehouf/Slotchouf, Sotchova/Cetchova, Vilanouf/Villanouf, Zamosch/ Zasoschi, Zolkief/Jolkiefldolkief. Szeroki zakres wariantywności może także wynikać z obszerności tekstu, w którym zawarto opis wydarzeń rozgrywających się w dość rozległej perspektywie czasowej. Trzeba też mieć na uwadze, że niektóre formy mogą być rezultatem błędów wydawcy. Ponadto oznak adaptacji do francuszczyzny należy upatrywać w stosowaniu determinantów (rodzajników określonych) w odniesieniu do pewnych kategorii nazw własnych (poza nazwami miast), np.: le Diestre, la Moravie, l’Ukraine, la Valakie, la Volhynie, co pozostaje w zgodzie z regułami gramatyki francuskiej.

${ }^{17}$ Szczegółowy opis zabiegów adaptacyjnych zastosowanych przez autora wymaga odrębnego studium.

${ }^{18}$ Chodzi o Lublin; początkowe $s$ jest najpewniej wynikiem pomyłki wydawcy.

${ }^{19}$ Z uwagą marginesową: „Il faut toujours se souvenir, que ces mots sont icy, comme on les prononce, \& non selon l'ortographe, qui est differente " (II/3) (,Musimy pamiętać, że te słowa są w takiej formie, w jakiej się je wymawia, nie według ortografii, która jest odmienna"). 
Warto zauważyć, że niektóre toponimy w tekście Daleraca stosowane są konsekwentnie w jednej tylko formie, zazwyczaj sfrancuszczonej, co dotyczy przede wszystkim nazw bardziej znanych, o szerszym zasięgu, które utrwaliły się także w postaci międzynarodowej. Do takich egzonimów należą: Bessarabie, Bouccovines, Courlande, Cracovie, Dantsiek, Danube, Lithüanie/Lithuanie, Moldavie/Moldave, Moravie, Moscovie, Oder, Pologne, Pomeranie, Prusse, Russie, Silesie, Transilvanie, Ukraine, Valakie, Warsovie/Varsovie, Volhynie, Vistule.

Jak można się przekonać z przytoczonych przykładów, spektrum technik, którymi posłużył się francuski autor w procesie prezentacji różnojęzycznych nazw własnych jest rozległe. Wykorzystane zabiegi z jednej strony stanowią konsekwencję zjawiska wynikającego z wielojęzyczności dzieła, z drugiej zaś są rezultatem dość złożonego układu nadawczo-odbiorczego, jaki zarysował się w pamiętniku. Nadawca - nosiciel języka francuskiego, posługujący się także innymi językami (w tym polskim) stworzył bowiem tekst przeznaczony nie dla przeciętnego odbiorcy francuskojęzycznego, ale dla czytelnika ciekawego świata, w tym przede wszystkim żywo zainteresowanego kwestiami językowymi. Zresztą do takiego czytelnika się dość często zwracał w „Les anecdotes...”, co ciekawe, raz utożsamiając się ze wspólnotą francuską, por. formuły typu ce que nous apellons ('to, co my (Francuzi) nazywamy...', les polonois ils apellent ('Polacy nazywają'), raz widząc już swoje miejsce po stronie Polaków, por. on nomme ici..., on apelle ici... ('nazywamy tu - czyli po polsku, w Polsce'). Zabieg ten, choć może być tylko figurą retoryczną, świadczy o przełamywaniu dystansu i zmianie optyki w odniesieniu do płaszczyzny swój — obcy.

Złożony charakter dzieła sprawia, że na zamieszczone w nim nazwy należy patrzeć z kilku perspektyw. Po pierwsze z perspektywy nadawcy i użytkownika języka francuskiego, także kogoś z zewnątrz, cudzoziemca, w którego uszach zdecydowana większość przywoływanych onimów miała egzotyczny charakter. Można ją określić mianem deskrypcyjnej, ponieważ autorowi chodziło przede wszystkim o zamieszczenie bogatego materiału onimicznego, który ułatwia orientację w opisywanych wydarzeniach (przy czym dodajmy, że nie we wszystkich brał on udział, niektóre bowiem opisał tylko niejako z kronikarskiego obowiązku). Po drugie, niemniej istotny wydaje się punkt widzenia człowieka żywo zainteresowanego kwestiami językowymi, filologa amatora, poligloty znającego także język polski. Po trzecie, z językoznawczej perspektywy współczesnego badacza - interpretacyjnej. W tym ujęciu jako istotny jawi się problem obcych nazw własnych, które w pamiętniku funkcjonują tak, jak w przekładzie. W ich transpozycji ścierają się dwie tendencje: do asymilacji graficzno-fonetycznej oraz translokacji w formie jak najbardziej zbliżonej do oryginału. Utrzymanie nazw (zwłaszcza translokowanych) pozwala w nich widzieć swego rodzaju wyznacznik etnolingwistyczny, który służy zachowaniu kolorytu lokalnego (Ballard, 2001, 
s. 203). Jednocześnie, by podnieść poziom komunikatywności przekazu, autor nie tylko zdecydował się na zamieszczenie w tekście zasadniczym form w różnym stopniu zasymilowanych (a warianty o charakterze cytatów czy do nich zbliżone wysunął na margines), ale także w odniesieniu do nazw o szerszym zasięgu, bardziej znanych poza Polską posłużył się egzonimami francuskimi, np.: Pologne, Lituanie, choć i w tym wypadku nie ustrzegł się choćby graficznych oboczności, $\mathrm{np}$. Varsovie//Warsovie. Zresztą na marginesie warto wspomnieć, iż formy typu Warsovie można interpretować jako nie w pełni zasymilowane. Trudno też powiedzieć, jaki zamysł kierował w takich przypadkach autorem: czy analogiczne zapisy są efektem nieuwagi, przeoczenia wynikającego z naturalnej trudności związanej z zapanowaniem nad tak obszernym zabytkiem, czy zostały wprowadzone celowo, by pozostawić polski ślad. W pamiętniku dokonuje się swego rodzaju transfer obcego (w tym w znacznej części polskiego) osiemnastowiecznego pejzażu onimicznego, umożliwiający percepcję świata przedstawionego odbiorcy francuskojęzycznemu, prymarnie frankofonowi. Po czwarte wreszcie, niebagatelną rolę w interpretacyjnym spojrzeniu językoznawczym odgrywa perspektywa socjolingwistyczna, związana z wielojęzycznością autora. Pamiętniki można uznać za przykład tekstu dwujęzycznego.

\section{LITERATURA}

Ballard, M. (2001). Le nom propre en traduction. Paris: Ophrys.

Cieślikowa, A. (1996). Jak „ocalić w thumaczeniu” nazwy własne? [How to save proper names in translation?]. W: J. Twardzikowa i M. Filipowicz-Rudek (red.), Między oryginałem a przekładem, II: Przektad, jego tworzenie się $i$ wplyw [Between the Original and the Translation, Part II: Translation, Its Formation and Impact] (s. 311-320). Kraków: Księgarnia Akademicka.

[Dalerac, F.P.] (1698). Memoires du Chevalier de Beaujeu (...) (1698). Paris: Claude Barbin. https://polona.pl/item/memoires-du-chevalier-de-beaujeu-contenant-ses-divers-voyages-tant-en-pologne-en,ODEzOTczNDY/

[Dalerac, F.P.] (1699). Les anecdotes de Pologne ou memoires secrets du regne de Jeans Sobieski III du nom (1699) (t. 1-2). Amsterdam: Henry Desbordes. https://polona.pl/item/les-anecdotes-de-pologne-ou-memoires-secrets-du-regne-de-jean-sobieski-iii-du-nom-tome,MTA5OTA3NTY0/; https://polona.pl/item/les-anecdotes-de-pologne-ou-memoires-secrets-du-regne-de-jean-sobieski-iii-du-nom-tome,MTA5OTA3NTc2/

[Dalerac, F.P.] (1883). Pamiętniki kawalera de Beaujeu [Memoirs of Chevalier de Beaujeu], przeł. i oprac. A. Kraushar. Kraków: Czcionkami Drukarni Związkowej pod zarządem A. Szyjewskiego. https://polona.pl/item/pamietniki-kawalera-de-beaujeu,MTU3NDkxODM/

Folkierski, W. (1925). Klopoty francuskiego autora XVII wieku z polszczyzna [Troubles of a French Author of the $17^{\text {th }}$ Century with the Polish Language]. Kraków: Drukarnia W. L. Anczyca i Spółki.

Gałkowski, A. (2018). Onomastyka translatoryczna a translatoryka onomastyczna [Translational onomastics and onomastic translation]. W: U. Bijak, H. Górny i M. Magda-Czekaj (red.), Onomastyka - neohumanistyka — nauki społeczne [Onomastics — Neohoumanities — Social Sciences] (s. 129-138). Kraków: IJP PAN. 
Górny, H. (2013). Nazwy własne w piśmiennictwie pamiętnikarskim XIX wieku. Perspektywa funkcjonalno-tekstologiczna [Proper Names in $19^{\text {th }}$ Century Memoir Writings. Functional-Textological Perspective]. Kraków: Lexis.

Hamers, J.F. i Blanc, M. (1983). Bilingualité et bilinguisme. Bruxelles: Mardaga.

Historya woyny wiedeńskiey z Turkami Jana III, króla polskiego. 1689 [History of the Battle of Vienna of the Polish King Jan III Against the Turks. 1689]. Zakład Narodowy im. Ossolińskich. Dział Rękopisów, sygn. 1993/I. https://www.dbc.wroc.pl/dlibra/doccontent?id=7989

MP = Szpetkowski, J. i Neumeyer, L. (1883). Mapa Polski za panowania króla Jana Sobieskiego wydana w dwóchsetną rocznicę od Wiednia przez J. Szpetkowskiego. Poznań: wyd. J. Szpetkowski. https://www.wbc.poznan.pl/dlibra/publication/535585/edition/474403/

$\mathrm{MU}=$ Ukrania quae et Terra Cosaccorum: cum vicinis Walachiae, Moldaviae, Minorisque Tartariae Provinciis (ok. 1712). Noribergae: J. Baptista Homanno. https://polona.pl/item/vkrania-quae-et-terra-cosaccorvm-cum-vicinis-walachiae-moldaviae-minoris-q-ue,Mzc0MTEzNA/

MWB = Beauplan, G. le Vasseur (1648). Delineatio generalis Camporum Desertorum vulgo Ukraina cum adjacentibus provinciis. https://commons.wikimedia.org/wiki/File:Beauplan_Poland_ XVII_map.jpg

Sanz Espinar, G. (2008). La traduction des noms propres (français - espagnol). W: Linguistique plurielle: Valencia. 25, 26 et 27 Octobre 2006 (s. 475-486). https://dialnet.unirioja.es/servlet/ articulo? codigo $=4031567$

$\mathrm{SG}=$ Chlebowski, B., Sulimierski, F. i Walewski, W. (red.). (1880-1902). Stownik geograficzny Królestwa Polskiego i innych krajów słowiańskich [Geographical Dictionary of the Polish Kingdom and other Slavic Countries]. Warszawa: Druk. „Wieku”. http://dir.icm.edu.pl/pl/ Slownik_geograficzny/

Szlezygier, J. (b.r.). Pamiętniki Daleraka z czasów panowania Jana III. Z francuskiego przetlumaczyt i przypisami objaśnit ... [Dalerac's Diaries From the Reign of Jan III. Translated and Edited by Józef Szlezygier] (t. 1-2). Lwowska Naukowa Biblioteka im. W. Stefanyka NAN Ukrainy. Oddział Rękopisów. Zespół (fond) 5. Rękopisy Biblioteki Zakładu Narodowego im. Ossolińskich, sygn. 4562/II.

Targosz, K. (1991). Jan III Sobieski mecenasem nauk i uczonych [Jan III Sobieski as a Patron of Sciences and Scientists]. Wrocław-Warszawa-Kraków: Zakład Narodowy im. Ossolińskich, PAN.

Targ o sz, K. (1992). Nieznane „portrety” Jana III i Marii Kazimiery pióra François Paulin Daleraca oraz ich autor [Unknown "portraits" of Jan III and Marie Casimire by François Paulin Dalerac, and their author]. Acta Universitatis Wratislaviensis. Historia, 102, 111-120.

Targo osz, K. (1997). Relacja księdza F. D. S. o Polsce czasów Jana III Sobieskiego (próba rozszyfrowania autorstwa) [The account of Father F. D. S. about Poland in the times of Jan III Sobieski (an attempt to establish the authorship)]. Kwartalnik Historii Nauki i Techniki, 42(3/4), 31-62.

Wolnicz-Pawłowska, E. (2006). Standaryzacja nazw geograficznych poza granicami Polski. Problematyka językowa [Standardization of geographical names beyond Polish borders. Linguistic issues]. Prace Językoznawcze, 8, 79-93.

Wolnicz-Pawłowska, E. (2014). Nazwy własne w przekładzie. Zarys problematyki [Proper names in translation. An outline of key topics]. Poznańskie Spotkania Językoznawcze, 27, 201-214. https://doi.org/10.14746/psj.2014.XXVII.17

Zarębski, R. (2018). Z dziejów językowych kontaktów polsko-francuskich. Polszczyzna w XVII-wiecznym pamiętniku F. P. Dalairaca pt. „Les anecdotes de Pologne ou memoires secrets du regne de Jean Sobieski III du nom" [From the history of Polish-French linguistic contacts. Polish in the 17th century F. Dalairac's memoir „Les anecdotes de Pologne ou memoires secrets du Pologne regne de Jean Sobieski III du nom"']. Poradnik Językowy, 2, 14-27. 


\section{SUMMARY}

GEOGRAPHICAL NAMES FROM $17^{\mathrm{TH}}$ CENTURY POLAND AND THE NEIGHBOURING REGIONS IN THE DIARY OF FRANCISZEK DALERAC TITLED "LES ANECDOTES DE POLOGNE OU MEMOIRES SECRETS DU REGNE DE JEAN SOBIESKI III DU NOM"

The aim of the article is to discuss various phenomena concerning the transposition of geographical names presented in the French diary of Franciszek Dalerac, the courtier of Polish King Jan Sobieski, and referring to places located in Poland in the second part of the $17^{\text {th }}$ century. The analysis is focused especially on those places situated in the area of the former eastern borderlines (Right-bank Ukraine and the area of Podolia with Kamianets) and the territories outside Poland that were important for Polish history, mainly areas belonging to the then Moldavia, Wallachia and Bukovina). The French polyglot was interested in linguistics and therefore included in his diary geographical names exotic to him. On the one hand, he tried to reflect their original Polish pronunciation and spelling and on the other he subjected them to adaptation.

Keywords: onymy, geographical name, language adaptation, translation, diary 